\title{
Histone deacetylase inhibitors induce cell death in supratentorial primitive neuroectodermal tumor cells
}

\author{
K. SARAVANA KUMAR ${ }^{1}$, JÜRGEN SONNEMANN ${ }^{1}$ and JAMES F. BECK ${ }^{2}$ \\ ${ }^{1}$ Research Center of Pharmacology and Experimental Therapeutics, ${ }^{2}$ Department of Pediatric Oncology/ \\ Hematology, Ernst Moritz Arndt University of Greifswald, D-17487 Greifswald, Germany
}

Received April 18, 2006; Accepted June 16, 2006

\begin{abstract}
Histone deacetylase inhibitors (HDIs) are a promising new class of antineoplastic agents with the capacity to induce differentiation and/or apoptosis of cancer cells. The objective of this study was to evaluate the activity of HDIs against supratentorial primitive neuroectodermal tumor (sPNET) cells. We show that the HDIs, suberoylanilide hydroxamic acid, sodium butyrate, and trichostatin A, induced cell death, and activated caspase- 3 and -9 in a sPNET cell line, PFSK. The poly-caspase inhibitor z-VAD-fmk partially prevented the action of HDIs, as judged by determining the mitochondrial membrane potential and by quantifying internucleosomal DNA fragmentation. In conclusion, the HDIs explored possess potent activity against sPNET cells, suggesting that HDIs may be effective in the treatment of sPNET.
\end{abstract}

\section{Introduction}

The supratentorial primitive neuroectodermal tumors (sPNETs) are embryonal central nervous system tumors primarily affecting young children. Together with medulloblastoma, sPNETs are among the most malignant childhood brain tumors. However, although sPNETs are histologically similar to medulloblastoma, they show different clinical behavior and are generally considered to be more aggressive than medulloblastoma. The contemporary treatment standard for sPNETs includes post-operative ionizing radiation and multiagent chemotherapy (1). However, the outcome for children with sPNET treated with radiation and chemotherapy appears worse than for children with medulloblastoma treated with identical therapy (2). Moreover, there are no effective therapies for most sPNETs that recur after previous radiation and chemotherapy.

Correspondence to: Dr James F. Beck, Zentrum für Kinder- und Jugendmedizin, Abteilung für Pädiatrische Onkologie und Hämatologie, Soldmannstrasse 15, D-17487 Greifswald, Germany E-mail: beck@uni-greifswald.de

Key words: supratentorial primitive neuroectodermal tumor, histone deacetylase inhibitors, suberoylanilide hydroxamic acid, sodium butyrate, trichostatin A
Thus, there is an imperative for new approaches that improve survival.

Inhibitors of histone deacetylases (HDIs) are presently emerging as a promising class of antineoplastic agents. HDIs are relatively specific anticancer drugs, which were originally identified by their capacity to reverse the transformed phenotype (3). Subsequently, they have been shown to reactivate gene expression and prevent proliferation, activate differentiation, and/or induce apoptosis of tumor cells (4). HDIs function by inhibiting histone deacetylases, resulting in the accumulation of acetylated histones, in turn leading to an increase in transcriptionally active chromatin. In so doing, they e.g. reactivate gene expression of dormant tumor suppressor genes, such as CDKN1A (p21) (5).

Recently, HDIs have been introduced as chemotherapeutic compounds. Their potent antitumor activity has been observed in cell lines originating from different types of human cancers as well as in studies on mice xenograft models of human neoplasia (4). Importantly, HDIs have been shown both in vitro and in vivo to affect cancer cells while leaving normal cells comparatively unscathed $(6,7)$. In addition, the clinical potential of these agents has been documented by several Phase I trials of different HDIs in patients with solid tumors or leukemias (8). With respect to sPNET, only the HDIs valproic acid (9) and depsipeptide (10) have been evaluated for their antitumor efficacy. A case report has demonstrated that valproic acid induced differentiation in a relapsed SPNET (11).

In a recent study, we have shown that HDIs were capable of effectively eliciting cell death in medulloblastoma cells (12). These findings prompted us to extend our studies to another brain neoplasm, sPNET. Herein, we report that the viability of sPNET PFSK cells could be potently reduced by treatment with three different HDIs belonging to two structural classes, the hydroxamic acids, suberoylanilide hydroxamic acid (SAHA) and trichostatin A (TSA), and the short chain fatty acid sodium butyrate $(\mathrm{NaB})$. Our results show that all three compounds triggered cell death in PFSK cells. In addition, we show that all three compounds activated caspase-3 and -9, and that the induction of cell death was partially caspase-dependent.

\section{Materials and methods}

Reagents. SAHA, TSA, and the pan-caspase inhibitor z-VADfmk were purchased from Alexis (Grünberg, Germany). NaB was purchased from Sigma (Deisenhofen, Germany). 
Cell culture. PFSK cells were a gift from Dr M. Grotzer (Zurich, Switzerland) and maintained in RPMI-1640 medium supplemented with $10 \%$ fetal calf serum, $2 \mathrm{mM} \mathrm{L-glutamine,}$ 100 units/ml penicillin $\mathrm{G}$ sodium, and $100 \mu \mathrm{g} / \mathrm{ml}$ streptomycin sulfate (medium and supplements were purchased from Biochrom, Berlin, Germany). Cells were cultivated at $37^{\circ} \mathrm{C}$ in a humidified $5 \% \mathrm{CO}_{2}$ incubator and routinely passaged when $90-95 \%$ confluent. Cell viability was determined by the trypan blue exclusion test. Cells were regularly inspected to be free of mycoplasma with mycoplasma detection reagents from Roche (Mannheim, Germany). To inhibit the activation of caspases, z-VAD-fmk was applied $1 \mathrm{~h}$ before treatment with HDIs.

Cytofluorometric analysis of cell death. To determine cell death, cells were harvested after a 24-h cultivation in the presence of HDIs, followed by a 5-min incubation in $2 \mu \mathrm{g} / \mathrm{ml}$ PI in PBS at $4^{\circ} \mathrm{C}$ in the dark. Propidium iodide (PI) (Sigma) uptake was assessed by flow cytometry analysis on a FACSCalibur using CellQuest software. Cells $(10,000)$ were analysed in each sample; data were gated to exclude debris.

Cytofluorometric analysis of DNA content. To measure DNA content, cells were analyzed for PI incorporation into DNA. Cells were harvested $24 \mathrm{~h}$ after treatment with HDIs, washed twice with PBS and fixed in $70 \%$ ethanol at $-20^{\circ} \mathrm{C}$ for at least 30 min. After centrifugation, cells were resuspended in PBS containing $1 \%$ glucose, $50 \mu \mathrm{g} / \mathrm{ml}$ RNase A (Roche) and $50 \mu \mathrm{g} /$ $\mathrm{ml} \mathrm{PI}$ and incubated in the dark at room temperature for $30 \mathrm{~min}$. Flow cytometry analysis was performed on a FACSCalibur using CellQuest software. Cells $(20,000)$ were analyzed in each sample; data were gated to exclude debris. sub- $\mathrm{G}_{1}, \mathrm{G}_{1}$ and $\mathrm{G}_{2} / \mathrm{M}$ phase cells were calculated from the DNA content histograms.

Cytofluorometric analysis of mitochondrial transmembrane potential $\left(\Delta \psi_{m}\right) . \Delta \psi_{\mathrm{m}}$ was determined by assessing the accumulation of the cationic lipophilic fluorochrome 3,3'dihexyloxacarbocyanine iodide $\left[\operatorname{DiOC}_{6}(3)\right]$ in the mitochondrial matrix. Twenty-four hours after treatment with HDIs, cells were incubated with $50 \mathrm{nM} \mathrm{DiOC}_{6}(3)$ (Molecular Probes, Eugene, OR, USA) at $37^{\circ} \mathrm{C}$ for $30 \mathrm{~min}$. After washing, 10,000 cells were analyzed using a FACSCalibur and CellQuest software. Data were gated to exclude debris.

Caspase-3 and -9 activities. Caspase activities were measured $24 \mathrm{~h}$ after treatment with HDIs using the synthetic fluorogenic substrates Ac-DEVD-AFC or Ac-LEHD-AFC (Bachem, Heidelberg, Germany) for determining caspase-3 and -9 activities, respectively. Cells were lysed in $10 \mathrm{mM}$ Tris- $\mathrm{HCl}$, $10 \mathrm{mM} \mathrm{NaH} \mathrm{PO}_{4} / \mathrm{NaHPO}_{4}(\mathrm{pH} 7.5), 130 \mathrm{mM} \mathrm{NaCl}, 1 \%$ Triton-X-100, and $10 \mathrm{mM} \mathrm{Na} \mathrm{P}_{2} \mathrm{O}_{7}$ and then incubated with $20 \mathrm{mM}$ Hepes (pH 7.5), $10 \%$ glycerol, $2 \mathrm{mM}$ DTT and $25 \mu \mathrm{g} /$ $\mathrm{ml} \mathrm{Ac-DEVD-AFC} \mathrm{or} 25 \mu \mathrm{g} / \mathrm{ml} \mathrm{Ac-LEHD-AFC}$ at $37^{\circ} \mathrm{C}$ for $2 \mathrm{~h}$. The release of trifluoromethylcoumarin (AFC) was analyzed on a Wallac Victor fluorometer (Perkin Elmer, Rodgau-Jügesheim, Germany) using an excitation/emission wavelength of 390/510 nm. Relative caspase activities were calculated as a ratio of emission of treated cells to untreated cells.

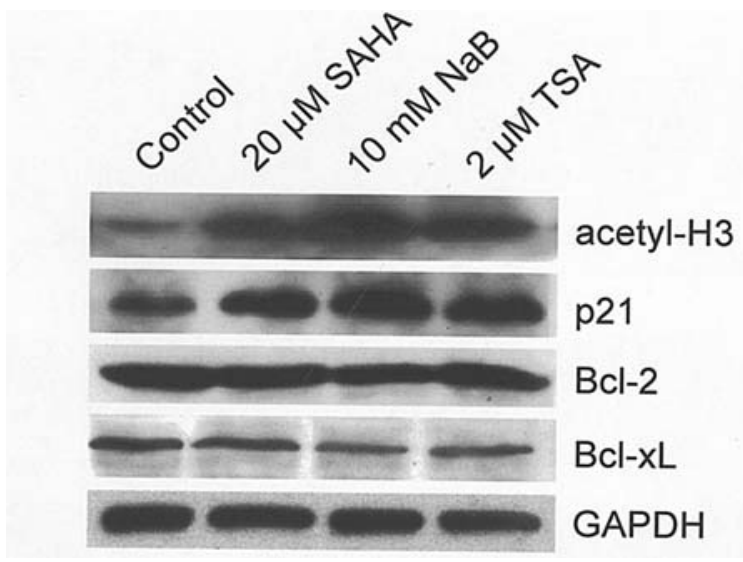

Figure 1. HDIs increase acetylation of histone H3. PFSK cells were treated for $24 \mathrm{~h}$ with the indicated concentrations of SAHA, NaB or TSA. Total protein $(30 \mu \mathrm{g})$ was separated by a $15 \%$ polyacrylamid gel. Western blot analyses were performed with antibodies against acetylated histone H3, p21, Bcl-2, and Bcl-xL. GAPDH was used as a loading control.

Western blot analysis. Cells were lysed on ice for $15 \mathrm{~min}$ in $40 \mathrm{mM}$ Tris- $\mathrm{HCl}$ (pH 7.4), $150 \mathrm{mM} \mathrm{NaCl}, 1 \%$ Triton X-100, $0.5 \%$ sodium deoxycholate, and $0.1 \%$ SDS supplemented with a protease inhibitor cocktail (Roche) followed by brief sonification. Protein concentration was assayed using bicinchoninic acid (Pierce, Rockford, IL, USA) according to the manufacturer's instructions. For immunoblotting, $30 \mu \mathrm{g}$ of total cellular protein per lane were separated by standard SDS-PAGE on $15 \%$ gels and electrophoretically transferred to PVDF membranes (Millipore, Eschborn, Germany). After blocking in PBS containing 5\% dry milk and $0.05 \%$ Tween-20, acetylated histone $\mathrm{H} 3$ was immunodetected using rabbit antiacetylated histone $\mathrm{H} 3$ polyclonal antibody (dilution 1:25,000; Upstate Biotechnology, Lake Placid, NY, USA). p21, Bcl-2, and $\mathrm{Bcl}-\mathrm{xL}$ were immunodetected using mouse anti-p21 (dilution 1:500), anti-Bcl-2 (dilution 1:500), and anti-Bcl-xL (dilution 1:1000) monoclonal antibodies (Santa Cruz Biotechnology, Heidelberg, Germany), respectively. Even loading of protein was verified by detection of GAPDH using mouse anti-GAPDH monoclonal antibody (dilution 1:10,000; Biodesign International, Saco, ME, USA). Peroxidaseconjugated goat anti-rabbit or anti-mouse IgGs (dilution 1:25,000; Dianova, Hamburg, Germany) followed by enhanced chemiluminescence (Amersham Biosciences, Freiburg, Germany) were used for detection.

Statistical analysis. Statistical significance of differences between experimental groups was determined using the paired two-tailed Student's t-test.

\section{Results}

HDI treatment leads to histone hyperacetylation and upregulation of p21 in PFSK cells. Initially, to determine whether HDIs would induce accumulation of acetylated histone H3 in PFSK cells, cells were treated with $20 \mu \mathrm{M}$ SAHA, $10 \mathrm{mM} \mathrm{NaB}$, or $2 \mu \mathrm{M}$ TSA for $24 \mathrm{~h}$, and the acetylation status of histone $\mathrm{H} 3$ was analyzed by Western blotting using an acetylated H3-specific antibody. As presented in Fig. 1, treatment with all three HDIs induced pronounced histone $\mathrm{H} 3$ hyperacetylation in PFSK cells. In addition, we 
SAHA

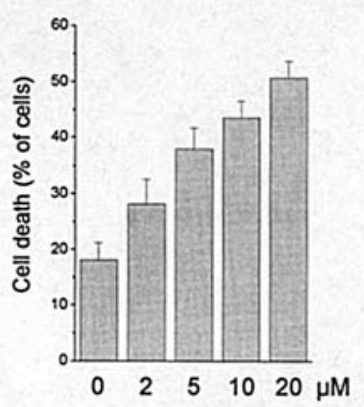

$\mathrm{NaB}$

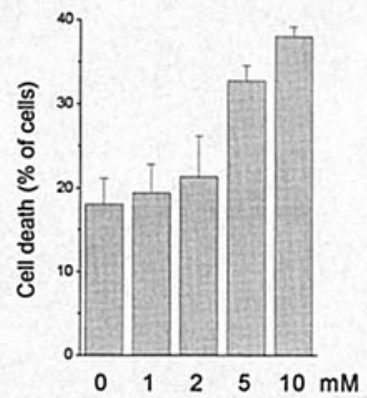

TSA

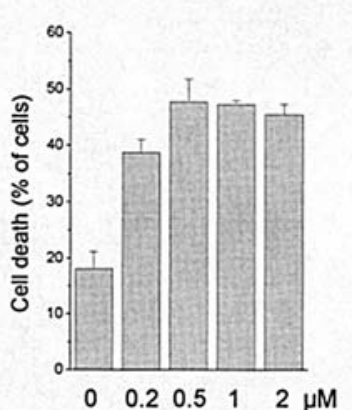

+ z-VAD-fmk

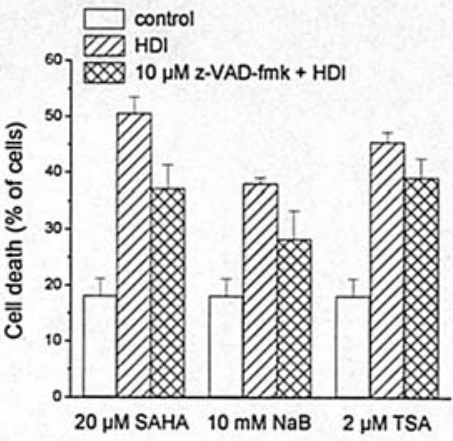

Figure 2. HDIs induce cell death. PFSK cells were incubated with SAHA, NaB, or TSA for $24 \mathrm{~h}$. z-VAD-fmk was applied $1 \mathrm{~h}$ before treatment with HDIs, cells were then incubated for $24 \mathrm{~h}$. Cell death was determined by cytofluorometric analysis of PI uptake. Means \pm SD of each 3 experiments are shown.

SAHA

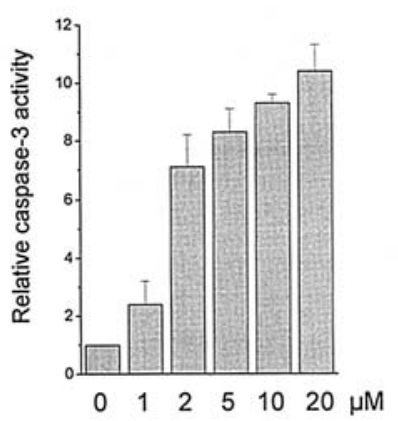

$\mathrm{NaB}$

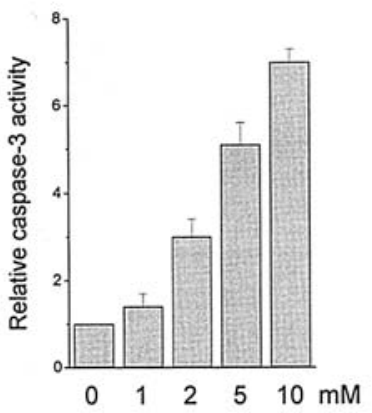

TSA

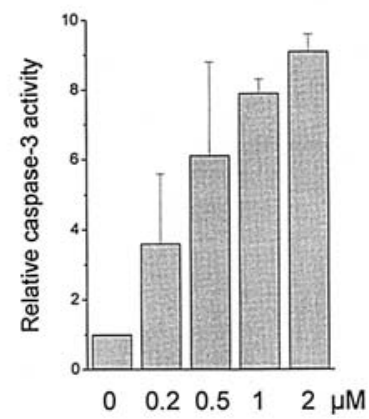

Figure 3. HDIs induce caspase-3 activity. PFSK cells were incubated with SAHA, NaB, or TSA for $24 \mathrm{~h}$. Caspase-3 activity was measured using the fluorogenic substrate Ac-DEVD-AFC. Relative caspase-3 activities are the ratio of treated cells to untreated cells. Means \pm SD of each 3 experiments are shown.

evaluated the level of $\mathrm{p} 21$ by immunoblot analysis: the three HDIs markedly increased p21 protein levels in PFSK cells.

HDIs induce cell death in PFSK cells. To assess possible cytotoxic effect of HDIs on sPNET cells, we monitored cell killing by determining the integrity of the cell membrane by cytofluorometric analysis of PI uptake. PFSK cell were cultured without or with varying doses of SAHA, NaB, or TSA for $24 \mathrm{~h}$. We observed a concentration-dependent increase in dead cells with increasing doses of the three compounds (Fig. 2). After treatment with $20 \mu \mathrm{M}$ SAHA, $10 \mathrm{mM} \mathrm{NaB}$, or $2 \mu \mathrm{M}$ TSA, $40-50 \%$ of cells underwent cell death. The pancaspase inhibitor partially - albeit not significantly - prevented cell killing induced by the three agents.

HDIs induce caspase-3 activity and DNA fragmentation in PFSK cells. Next, we assessed whether HDI-induced cell death in PFSK cells would involve apoptosis. Induction of the caspase pathway is one of the hallmarks of apoptosis (13). Accordingly, its activity is considered as a suitable measure of apoptotic responsiveness. We determined the dose-response relationship of HDI-induced caspase-3 activity after a 24-h incubation of PFSK cells with increasing concentrations of HDIs. SAHA, NaB, and TSA triggered caspase-3 activity in a dose-dependent manner, with 10-, 7-, or 9-fold activation of caspase-3, respectively, being observed at the highest concentrations applied (Fig 3).

Apoptosis was determined by cell cycle analysis; the sub$\mathrm{G}_{1}$ population of cells is indicative of apoptosis. Cell cycle distribution was assessed by staining the nuclei of ethanolfixed cells with PI and quantifying the percentage of each cell cycle phase by cytofluorometry. The analysis revealed a progressive accumulation of the sub- $\mathrm{G}_{1}$ fraction of cells over increasing concentrations of HDIs, concomitant with a decrease of cells within $\mathrm{G}_{1}$ and $\mathrm{G}_{2} / \mathrm{M}$ (Fig. 4). At low concentrations, HDIs caused an accumulation of cells with 4 n DNA content, consistent with a $\mathrm{G}_{2} / \mathrm{M}$ cell cycle arrest. $\mathrm{z}-\mathrm{VAD}$-fmk was used to assess whether HDI-induced DNA fragmentation was caspase dependent. Cells were cultured with HDIs in the presence or absence of $10 \mu \mathrm{M} \mathrm{z}$-VAD-fmk. Cytofluorometric analysis revealed a significant reduction of sub- $\mathrm{G}_{1}$ cells in the presence of the caspase inhibitor.

HDIs induce dissipation of the mitochondrial membrane potential $\left(\Delta \psi_{m}\right)$ and caspase-9 activity in PFSK cells. HDIs have been reported to harness the mitochondrial pathway of apoptosis (14-16). To evaluate the participation of mito- 
SAHA

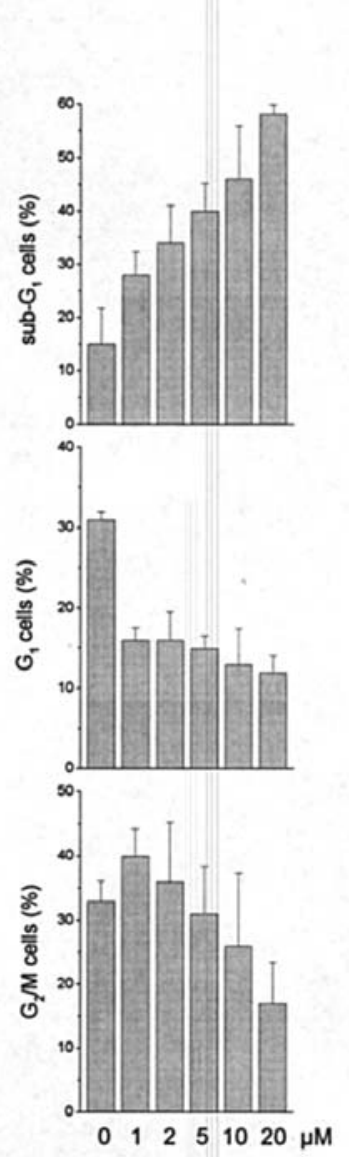

$\mathrm{NaB}$
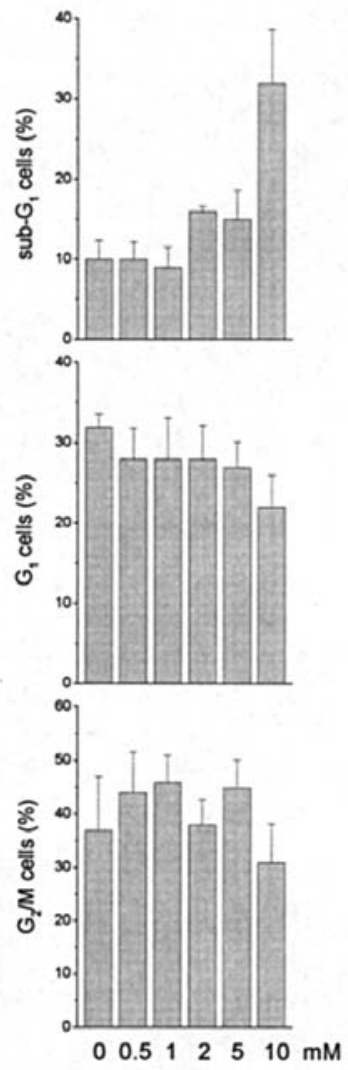

TSA
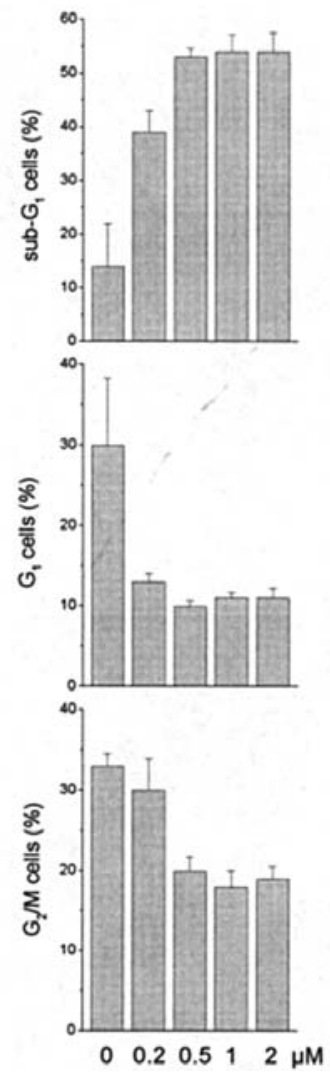

+ z-VAD-fmk
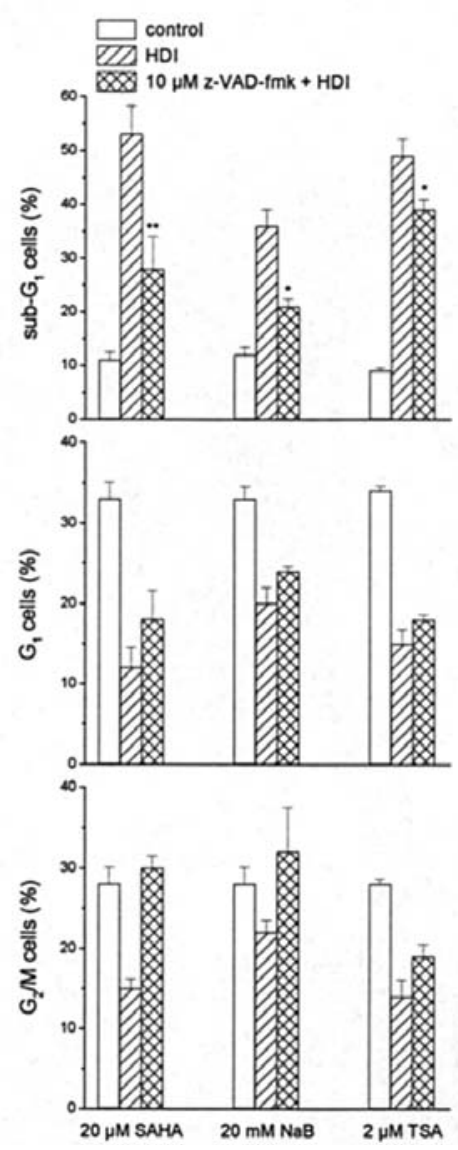

Figure 4. HDIs alter cell cycle profile. PFSK cells were incubated with SAHA, NaB, or TSA for $24 \mathrm{~h}$. z-VAD-fmk was applied $1 \mathrm{~h}$ before treatment with HDIs, cells were then incubated for $24 \mathrm{~h}$. Cell cycle profiles were analyzed by flow cytometry. Means \pm SD of each 3 experiments are shown ${ }^{*}$ p $<0.05$, $\left.{ }^{* *} \mathrm{p}<0.005\right)$.

chondria in the apoptotic process triggered by HDIs in PFSK cells, we assessed the effects of SAHA, NaB, or TSA on mitochondria by determining $\Delta \psi_{\mathrm{m}}$. As depicted in Fig. 5A, a 24-h incubation with increasing concentrations of HDIs caused a significant decay of $\Delta \psi_{\mathrm{m}}$ in PFSK cells in a dosedependent manner. The $\Delta \psi_{\mathrm{m}}$ loss was reduced by pretreatment with $10 \mu \mathrm{M} \mathrm{z}$-VAD-fmk, demonstrating that the mitochondrial function in HDI-mediated apoptosis is at least partially caspase-dependent.

Typically, the permeabilization of mitochondria is accompanied by the release of cytochrome $\mathrm{c}$ into the cytosol, concomitant with the activation of caspase-9. We thus tested whether HDIs would stimulate caspase-9 activity in PFSK cells. Fig. 5B shows that SAHA, NaB, and TSA activated caspase- 9 in a dose-dependent manner, with a 12-, 3.5-, and 10 -fold activation of caspase-9, respectively, being measured at the highest doses administered.

The mitochondrial pathway of apoptosis is controlled by proteins of the Bcl-2 family (17). Likewise, HDI-induced mitochondria-dependent apoptosis has been reported to be associated with the downregulation of the antiapoptotic factors, Bcl-2 and Bcl-xL $(15,16)$. On the other hand, $\mathrm{NaB}$ has been shown to upregulate Bcl-2 and Bcl-xL in hepatocarcinoma cells (18). To clarify whether HDIs would also affect the expression of these proteins in PFSK cells, their expression levels were analyzed by Western blotting. As illustrated in Fig. 1, treatment with SAHA, NaB or TSA did not result in significant changes of Bcl-2 or Bcl-xL levels in PFSK cells.

\section{Discussion}

Medulloblastoma and sPNET are highly malignant childhood brain tumors with poor prognosis. In a recent study, we have demonstrated that HDIs are effective in inducing cell death in medulloblastoma cells and may thus be useful for the treatment of medulloblastoma (12). In the present study, we demonstrate that the HDIs explored, SAHA, NaB, and TSA, also possess potent antineoplastic activity against sPNET cells. All three agents were effective in inducing cell death in PFSK sPNET cells, as evidenced by cytofluorometric PI uptake analysis. Cell killing was paralleled by the accumulation of acetylated histone H3 after culture of PFSK cells with HDIs, demonstrating the histone deacetylase inhibitory activity of SAHA, $\mathrm{NaB}$, and TSA in sPNET cells. p21 has repeatedly been shown to be upregulated by various HDIs $(5,19,20)$; its induction, thus, serves as an additional marker for the activity of these compounds. Exposure of PFSK cells to SAHA, NaB, or TSA resulted in the upregulation of $\mathrm{p} 21$, providing further evidence for the action of these HDIs in sPNET cells. 
A SAHA

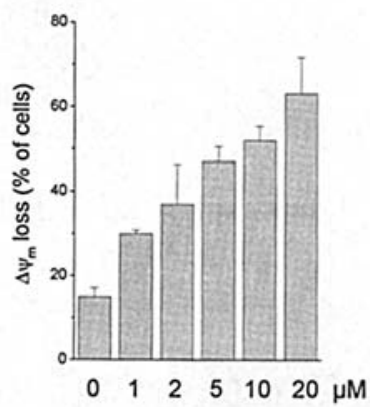

$\mathrm{NaB}$

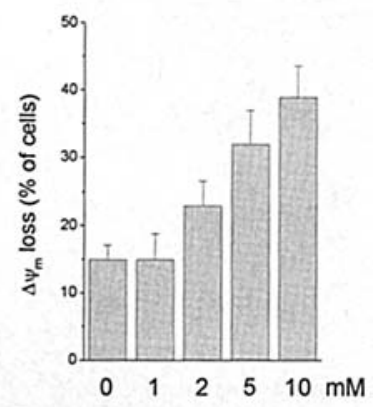

TSA

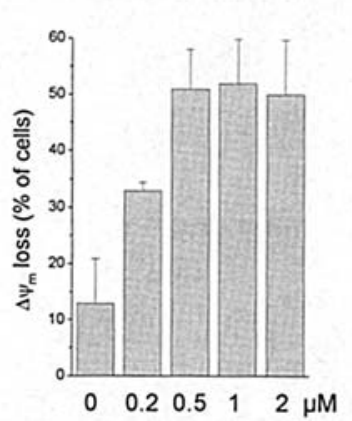

+ z-VAD-fmk

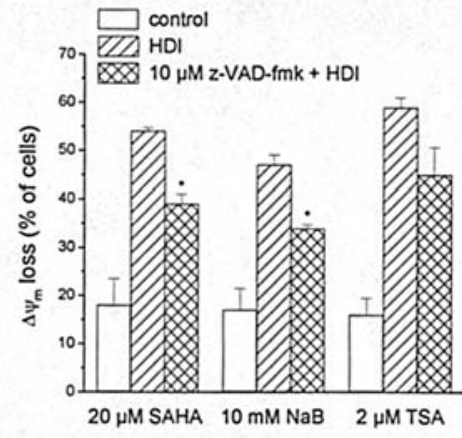

B

SAHA

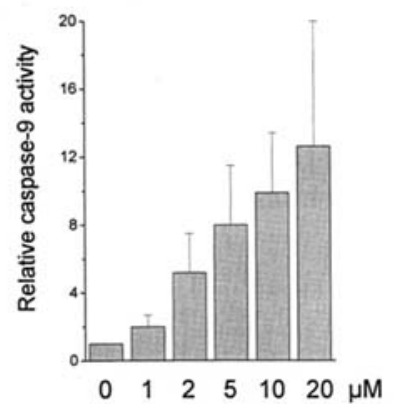

$\mathrm{NaB}$

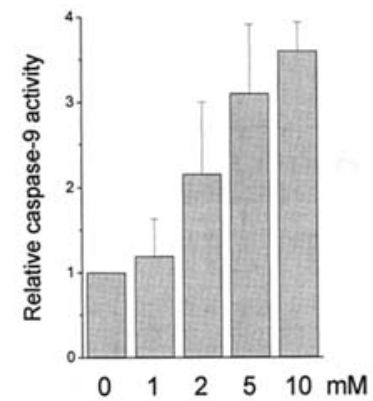

TSA

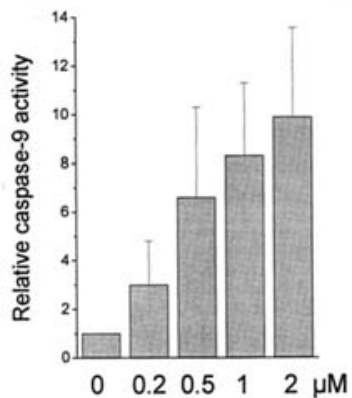

Figure 5. HDIs induce $\Delta \psi_{\mathrm{m}}$ dissipation and caspase-9 activity. (A) $\Delta \psi_{\mathrm{m}}$ dissipation. PFSK cells were incubated with SAHA, NaB, or TSA for 24 h. $\mathrm{z}$-VADfmk was applied $1 \mathrm{~h}$ before treatment with HDIs, cells were then incubated for $24 \mathrm{~h} . \Delta \psi_{\mathrm{m}}$ was assessed by cytofluorometric analysis of DiOC 6 (3) staining. Means \pm SD of each 3 experiments are shown $\left({ }^{*} \mathrm{p}<0.05\right)$. (B) Caspase-9 activity. PFSK cells were incubated with SAHA, NaB, or TSA for 24 h. Caspase- 9 activity was measured using the fluorogenic substrate Ac-LEHD-AFC. Relative caspase- 9 activities are the ratio of treated cells to untreated cells. Means \pm SD of each 3 experiments are shown.

HDIs have been reported to exert their cytotoxic effects by inducing apoptosis (21) as well as by different other mechanisms (22-24). Herein, we present evidence that SAHA, $\mathrm{NaB}$, and TSA triggered cell death in PFSK cells through the induction of apoptosis. We found that exposure to these agents led to the accumulation of sub- $\mathrm{G}_{1}$ cells, a finding that is consistent with DNA fragmentation and apoptosis. We also found that these HDIs potently activated caspase-3, another feature characteristic for apoptosis. However, whether activation of caspases is required for HDI-induced cell death is uncertain. Some studies point to a critical role of caspases for HDI-mediated cell death $(12,25,26)$, whereas others suggest a caspase-independent mechanism $(14,27)$. In this study, experiments using the polycaspase inhibitor z-VADfmk revealed that activated caspases were indeed required for HDI-induced cytotoxic effects in PFSK cells, as judged by assessing DNA fragmentation, and by measuring $\Delta \psi_{\mathrm{m}}$. The only incomplete protection against HDI-triggered activities by z-VAD-fmk may be explicable by the existence of caspaseindependent cell death mechanisms or, alternatively, by residual caspase activities due to the relatively low dose of z-VAD-fmk applied. As with other chemotherapeutic drugs, the intrinsic pathway of apoptosis is central to HDI-induced cell death (21). In concordance, in our study, SAHA, NaB, and TSA induced loss of mitochondrial membrane potential paralleled by the activation of caspase- 9 , demonstrating the functionality of the mitochondrial pathway in HDI-triggered apoptosis in sPNET cells. Typically, this pathway is regulated by proteins of the Bcl-2 family (17). However, in the sPNET cell line examined, treatment with HDIs did not cause significant expression changes of the antiapoptotic factors, $\mathrm{Bcl}-2$ and $\mathrm{Bcl}-\mathrm{xL}$. Thus, these proteins do not appear to have a substantial role in HDI-induced cell death in sPNET cells.

In conclusion, our study provides evidence that HDIs possess anticancer activity in sPNET cells. This finding is consistent with our previous work demonstrating that SAHA, $\mathrm{NaB}$, and TSA elicit cell death in medulloblastoma cells (12). Taken together, these studies support the notion that HDIs warrant a more in-depth investigation for their potential use in the therapy of childhood brain cancers.

\section{Acknowledgements}

We thank J. Gänge, U. Glawe, and A. Plath for excellent technical assistance. This work was supported by a grant from the Deutsche Krebshilfe.

\section{References}

1. Timmermann B, Kortmann RD, Kuhl J, Meisner C, Dieckmann K, Pietsch T and Bamberg M: Role of radiotherapy in the treatment of supratentorial primitive neuroectodermal tumors in childhood: results of the prospective German brain tumor trials HIT 88/89 and 91. J Clin Oncol 20: 842-849, 2002. 
2. Reddy AT, Janss AJ, Phillips PC, Weiss HL and Packer RJ: Outcome for children with supratentorial primitive neuroectodermal tumors treated with surgery, radiation, and chemotherapy. Cancer 88: 2189-2193, 2000.

3. Marks P, Rifkind RA, Richon VM, Breslow R, Miller T and Kelly WK: Histone deacetylases and cancer: causes and therapies. Nat Rev Cancer 1: 194-202, 2001.

4. Drummond DC, Noble CO, Kirpotin DB, Guo Z, Scott GK and Benz CC: Clinical development of histone deacetylase inhibitors as anticancer agents. Annu Rev Pharmacol Toxicol 45: 495-528, 2005.

5. Richon VM, Sandhoff TW, Rifkind RA and Marks PA: Histone deacetylase inhibitor selectively induces p21WAF1 expression and gene-associated histone acetylation. Proc Natl Acad Sci USA 97: 10014-10019, 2000.

6. Butler LM, Agus DB, Scher HI, Higgins B, Cordon-Cardo C, Rose A, Thaler HT, Rifkind RA, Marks PA and Richon VM: Suberoylanilide hydroxamic acid, an inhibitor of histone deacetylase, suppresses the growth of prostate cancer cells in vitro and in vivo. Cancer Res 60: 5165-5170, 2000.

7. He LZ, Tolentino T, Grayson P, Zhong S, Warrell RP Jr, Rifkind RA, Marks PA, Richon VM and Pandolfi PP: Histone deacetylase inhibitors induce remission in transgenic models of therapy-resistant acute promyelocytic leukemia. J Clin Invest 108: 1321-1330, 2001

8. Kouraklis $\mathrm{G}$ and Theocharis S: Histone deacetylase inhibitors: A novel target of anticancer therapy (Review). Oncol Rep 15: 489-494, 2006

9. Li XN, Shu Q, Su JM, Perlaky L, Blaney SM and Lau CC: Valproic acid induces growth arrest, apoptosis, and senescence in medulloblastomas by increasing histone hyperacetylation and regulating expression of p21Cip1, CDK4, and CMYC. Mol Cancer Ther 4: 1912-1922, 2005.

10. Graham C, Tucker C, Creech J, Favours E, Billups CA, Liu T, Fouladi M, Freeman BB III, Stewart CF and Houghton PJ: Evaluation of the antitumor efficacy, pharmacokinetics, and pharmacodynamics of the histone deacetylase inhibitor depsipeptide in childhood cancer models in vivo. Clin Cancer Res 12: 223-234, 2006.

11. Driever PH, Wagner S, Hofstadter F and Wolff JE: Valproic acid induces differentiation of a supratentorial primitive neuroectodermal tumor. Pediatr Hematol Oncol 21: 743-751, 2004.

12. Sonnemann J, Kumar KS, Heesch S, Muller C, Hartwig C, Maass M, Bader P and Beck JF: Histone deacetylase inhibitors induce cell death and enhance the susceptibility to ionizing radiation, etoposide, and TRAIL in medulloblastoma cells. Int J Oncol 28: 755-766, 2006.

13. Fischer U, Janicke RU and Schulze-Osthoff K: Many cuts to ruin: a comprehensive update of caspase substrates. Cell Death Differ 10: 76-100, 2003.

14. Peart MJ, Tainton KM, Ruefli AA, Dear AE, Sedelies KA, O'Reilly LA, Waterhouse NJ, Trapani JA and Johnstone RW: Novel mechanisms of apoptosis induced by histone deacetylase inhibitors. Cancer Res 63: 4460-4471, 2003.

15. Zhang XD, Gillespie SK, Borrow JM and Hersey P: The histone deacetylase inhibitor suberic bishydroxamate regulates the expression of multiple apoptotic mediators and induces mitochondria-dependent apoptosis of melanoma cells. Mol Cancer Ther 3: 425-435, 2004.
16. Doi S, Soda H, Oka M, Tsurutani J, Kitazaki T, Nakamura Y, Fukuda M, Yamada Y, Kamihira S and Kohno S: The histone deacetylase inhibitor FR901228 induces caspase-dependent apoptosis via the mitochondrial pathway in small cell lung cancer cells. Mol Cancer Ther 3: 1397-1402, 2004.

17. Cory S and Adams JM: The Bcl2 family: regulators of the cellular life-or-death switch. Nat Rev Cancer 2: 647-656, 2002 .

18. Wakabayashi K, Saito H, Ebinuma H, Saito Y, Takagi T, Nakamura M, Umezawa A, Hata J and Ishii H: Bcl-2 related proteins are dramatically induced at the early stage of differentiation in human liver cancer cells by a histone deacetylase inhibitor projecting an anti-apoptotic role during this period. Oncol Rep 7: 285-288, 2000.

19. Blagosklonny MV, Robey R, Sackett DL, Du L, Traganos F, Darzynkiewicz Z, Fojo T and Bates SE: Histone deacetylase inhibitors all induce p2 1 but differentially cause tubulin acetylation, mitotic arrest, and cytotoxicity. Mol Cancer Ther 1: 937-941, 2002.

20. Rocchi P, Tonelli R, Camerin C, Purgato S, Fronza R, Bianucci F, Guerra F, Pession A and Ferreri AM: p21Waf1/Cip1 is a common target induced by short-chain fatty acid HDAC inhibitors (valproic acid, tributyrin and sodium butyrate) in neuroblastoma cells. Oncol Rep 13: 1139-1144, 2005.

21. Mei S, Ho AD and Mahlknecht U: Role of histone deacetylase inhibitors in the treatment of cancer (Review). Int J Oncol 25: 1509-1519, 2004.

22. Ogryzko VV, Hirai TH, Russanova VR, Barbie DA and Howard BH: Human fibroblast commitment to a senescencelike state in response to histone deacetylase inhibitors is cell cycle dependent. Mol Cell Biol 16: 5210-5218, 1996.

23. Shao Y, Gao Z, Marks PA and Jiang X: Apoptotic and autophagic cell death induced by histone deacetylase inhibitors. Proc Natl Acad Sci USA 101: 18030-18035, 2004.

24. Xu WS, Perez G, Ngo L, Gui CY and Marks PA: Induction of polyploidy by histone deacetylase inhibitor: a pathway for antitumor effects. Cancer Res 65: 7832-7839, 2005.

25. Henderson C, Mizzau M, Paroni G, Maestro R, Schneider C and Brancolini C: Role of caspases, Bid, and p53 in the apoptotic response triggered by histone deacetylase inhibitors trichostatin-A (TSA) and suberoylanilide hydroxamic acid (SAHA). J Biol Chem 278: 12579-12589, 2003.

26. Sonnemann J, Hartwig M, Plath A, Saravana KK, Muller C and Beck JF: Histone deacetylase inhibitors require caspase activity to induce apoptosis in lung and prostate carcinoma cells. Cancer Lett 232: 148-160, 2006.

27. Ruefli AA, Ausserlechner MJ, Bernhard D, Sutton VR, Tainton KM, Kofler R, Smyth MJ and Johnstone RW: The histone deacetylase inhibitor and chemotherapeutic agent suberoylanilide hydroxamic acid (SAHA) induces a celldeath pathway characterized by cleavage of Bid and production of reactive oxygen species. Proc Natl Acad Sci USA 98: 10833-10838, 2001. 